\title{
15
}

\section{Film Clubs, Festivals, Archives, and Magazines}

\author{
Ferran Alberich, Román Gubern, \\ and Vicente Sánchez-Biosca
}

\section{Film Clubs (Román Gubern)}

Film clubs have played a major role in Spain, in introducing the late 1920s Spanish avant-garde to European experimental cinema, and, under the Franco dictatorship, in exposing largely student audiences to a wider range of international cinema than was accessible in commercial venues, as well as encouraging social readings of film texts that helped to shape the consciousness of the anti-Franco opposition. A key feature of these film clubs was a pedagogical concern to produce an intellectual elite that, whether for artistic or political reasons, sought to distinguish itself from the general public for commercial cinema.

Private screenings were organized for film lovers in several cities throughout the 1920s, but the start of cineclubismo, as the phenomenon is called in Spain, is usually given as May 1927, when Luis Buñuel started to organize cinema sessions at Madrid's elite university hall of residence, the Residencia de Estudiantes, as part of its extracurricular program (see Gubern 1999: 260-70). Buñuel introduced the sessions personally. The first May 1927 session screened Rien que les heures / Nothing but Time (Alberto Cavalcanti, 1930) and Entr'acte (René Clair, 1924), together with examples of accelerated and slow motion and a dream sequence from La Fille de l'eau / Whirlpool of Fate (Jean Renoir, 1924). The March 1928 session screened La Coquille et le clergyman / The Seashell and the Clergyman (Germaine Dulac, 1927) and La Glace à trois faces / The Three-sided Mirror (Jean Epstein, 1927). The December 1928 session, held at the Teatro Princesa, screened La Passion de Jeanne d'Arc / The Passion of Joan of Arc (Carl Th. Dreyer, 1928), with an introductory lecture by Valentine Victor Hugo. The success of these screenings led to the creation of the 
Cineclub Español, linked to the cultural magazine La Gaceta Literaria (see Gubern 1999: 271-389). Both the film club and the magazine were directed by Ernesto Giménez Caballero; the magazine's film feature was, from the second issue in January 1927, run by Buñuel, who would write ten articles for it through April 1929. Cineclub Español's creation was announced in October 1928, though its first session did not take place until December 23. Its organizing committee combined intellectuals and aristocrats, and Buñuel did the programming from Paris up to its sixth session, devoted to film comedies (May 4, 1929). From then on, Giménez Caballero took over programming with input from César M. Arconada, Juan Piqueras, Luis Gómez Mesa, and Miguel Pérez Ferrero. Its members included avant-garde writers and artists such as Ramón Gómez de la Serna, Rafael Alberti, Federico García Lorca, Rosa Chacel, Maruja Mallo, José Moreno Villa, Vicente Aleixandre, and José Bergamín, and the radio (and later film) empresario Ricardo Urgoiti (for Urgoiti, see the section "Filmófono" in Chapter 15). This cinephile elite was captured on celluloid by Giménez Caballero in his remarkable avantgarde documentary Noticiario del cineclub / Film Club News (1930).

Buñuel had wanted to inaugurate the Cineclub Español's sessions with Erich von Stroheim's Greed (1923) but MGM refused permission, fearing it would go down badly. Programming for its twenty-one sessions, held between December 1928 and May 1931, was eclectic. It combined work by established directors (Das Wachsfigurenkabinett / Waxworks (Paul Leni, 1924), Tartüff / Tartuffe (F. W. Murnau 1925), Feu Mathias Pascal / The Living Dead Man (Marcel L'Herbier, 1926), La Chute de la maison Usher / The Fall of the House of Usher (Jean Epstein, 1928), Un chapeau de paille d'Italie / The Horse Ate the Hat (René Clair, 1928), Sous les toits de Paris / Under the Roofs of Paris (Clair, 1930)) with experimental films (Schatten / Warning Shadows (Artur Robison, 1923), Le Ballet mécanique (Dudley Murphy and Fernand Léger, 1924), La Marche des machines / The March of the Machines (Eugène Deslaw, 1927), Lonesome (Paul Fejos, 1928), La Perle / The Pearl (Georges Hugnet, 1929), and Buñuel's own Un chien andalou (1929), shown on December 8, 1929). In addition, it screened documentary films (Moana (Robert Flaherty, 1926), Skyscraper Symphony (Robert Florey, 1929), Esencia de verbena / Essence of Carnival (Giménez Caballero, 1930), the zoological documentaries of Jean Painlevé); feminist cinema (La Souriante madame Beudet / The Smiling Madame Beudet (Germaine Dulac, 1923)); the new sound cinema (The Jazz Singer (Alan Crosland, 1927), which was booed because it was not shown with the original soundtrack, Deutsche Rundfunk / German Radio Broadcasting (Walter Ruttmann, 1928)); Soviet cinema (Battleship Potemkin (Sergei M. Eisenstein, 1925), which was screened at the final session, Storm over Asia (Vsevolod Pudovkin, 1928), Women of Ryazan (Olga Preobrazhenskaya, 1928), The General Line (Eisenstein, 1929)); Chinese cinema; film comedies; and cartoons. The only Spanish film shown was fragments of Francisco Camacho's 1929 Zalacain el aventurero / Zalacain the Adventurer, based on Pío Baroja's novel and then at postproduction stage. The presenters included Giménez Caballero, as well as Buñuel, the French director Dulac, Urgoiti, the eminent doctor Gregorio Marañón, and the 
writers Gómez de la Serna, Alberti, García Lorca, Baroja, Benjamín Jarnés, and Eugenio Montes.

Barcelona's role as the center of the early Spanish film industry should not be forgotten. In April 1929 the Barcelona cultural weekly Mirador (1929-37), whose film column was run by Josep Palau, started its Sesiones Mirador, with similar programming including films by Buñuel, Epstein, Clair, Deslaw, Man Ray, Cavalcanti, Henri Chomette, Hugnet, Murnau, Pudovkin, and Howard Hawks, among others. It organized the Spanish première of Un chien andalou (October 24, 1929 ) and the first screening in Spain of Soviet cinema (Pudovkin's Storm over Asia on November 28, 1929). In November 1930, after its eleventh session, Mirador announced that its screenings would be organized in collaboration with the distributor Cinaes, which had been running its own film club since that January. Their first joint session (November 7, 1930) again scored a first, with the Spanish première of Battleship Potemkin (screened by Madrid's Cineclub Español in May 1931). This collaboration was short-lived and Cinestudio Cinaes' private sessions continued independently of Sesiones Mirador, while other film clubs sprang up in the city: Barcelona Film Club, Horitzons, and Cine Amateur.

The declaration of the Second Republic in April 1931, ushering in new public freedoms, stimulated a rapid growth of film clubs. The Madrid distributor Filmófono, headed by Urgoiti with Buñuel as advisor, started private screenings at the Proa-Filmófono film studio on December 20, 1932 with Kameradeschaft / Comradeship (G. W. Pabst, 1931). Urgoiti invited Giménez Caballero to its inaugural session, which it regarded as a continuation of his Cineclub Español, but the latter publicly declined, bitterly alleging that he had been sidelined by the new Republican regime. Proa-Filmófono studio's programming favored Soviet cinema, chosen by Juan Piqueras from Paris. Its 1932 sessions included The General Line (Eisenstein), October (Eisenstein, 1929), Turksib (Victor Turin, 1929; a documentary on the building of the Turkestan-Siberia railroad), Earth (Aleksandr Dovzhenko, 1930), and Das Lied von Leben / Song of Life (Alexis Granowski, 1931). Also screened in 1932 were The Crowd (King Vidor, 1928), The Wind (Victor Sjöström, 1928), Melodie der Welt / Melody of the World (Ruttmann, 1929), Le Sang d'un poète / Blood of a Poet (Jean Cocteau, 1930; presented by Rafael Gil), À nous la liberté (Clair, 1931), Berlin Alexanderplatz (Phil Jutzi, 1931), and Die Koffer des Herrn O. F. / Mr. O. F.'s Suitcases (Granowsky, 1931). Included in its 1933 program were Regen / Rain (Joris Ivens, 1929), La Chienne / Isn't Life a Bitch? (Renoir, 1931), L'Opéra des quat'sous / The Threepenny Opera (Pabst, 1931), Road to Life (Nikolai Ekk, 1931), Kuhle Wampe (Slatan Dudow, 1932), and Vampyr / Not against the Flesh (Dreyer, 1932). This mix of artistic and political innovation was the hallmark of film club programming in those years. Filmófono, like Cinaes, was a distributor, which allowed it to promote certain films that it then released commercially in cinema theaters. Thus, between March and May 1931 (spanning the transition to the Republic), Cinaes exhibited in Barcelona Mother (Pudovkin, 1926), Voyage au Congo / Journey to the Congo (Marc Allégret and André Gide, 1927), Les Deux timides / Two Timid Souls (Clair, 1928), 
Vormittagspuk / Ghosts before Breakfast (Hans Richter, 1928), Regen (1929), China Express (Ilya Trauberg, 1930), The Dawn Patrol (Howard Hawks, 1930), Esencia de verbena (1930), Liliom (Frank Borzage, 1930), and Stürme über dem Montblanc / Avalanche (Arnold Fanck, 1930). Although Spanish cinema was rarely screened by these film clubs, Cinestudio Cinaes did show Edgar Neville's Falso noticiario / Fake Newsreel (1933).

Film clubs fulfilled a useful function by offering private screenings of controversial film that, even with the general permissiveness under the Republic, could be screened only with precautionary measures. Banned in France, Buñuel's L'Âge d'or was shown in a private session at Urgoiti's Palacio de la Prensa Cinema in Madrid on November 22, 1931, and was screened again at the same venue, with Un chien andalou, on October 29, 1933. Barcelona's Cinestudio Cinaes and Cineclub Mirador screened it in January 1933 and May 1934 respectively, with some cuts ordered by the civil governor, though in June 1934 the Agrupació d'Amics de l'Art Nou (ADLAN; Association of Friends of Modern Art) advertised its exhibition in uncut form. The Grupo de Escritores Cinematográficos Independientes (GECI; Independent Film Writers Group), comprising Antonio Barbero, Rafael Gil, Luis Gómez Mesa, Benjamín Jarnés, and Manuel Villegas López, issued a founding manifesto in Madrid on September 26, 1933 blaming commercial publicity for corrupting film criticism. GECI's film club, inaugurated in November 1933, held thirty sessions through 1936, and published Villegas López's Cita de ensueños (Appointment with Dreams) and Gil's Luz del cinema (Film Light). Villegas López was also the driving force behind Madrid's Cinestudio Imagen (not to be confused with the film club Cinestudio 33, also created in 1933). In December 1933, Cinestudio Imagen premiered Buñuel's documentary Las Hurdes / Land without Bread in a screening without soundtrack but with live commentary by the filmmaker. As noted in the section on censorship in Chapter 14, this documentary was banned from exhibition under the Radical-CEDA (Confederación Española de Derechas Autónomas) coalition government of November 1933 to January 1936 and not shown again until after Popular Front victory in February 1936, when it was screened at the same film club.

Under the Republic, film clubs also became a proletarian phenomenon. The magazine Nuestro Cinema, directed by the communist Juan Piqueras, convened a meeting of film club organizers in Madrid in July 1933, which produced a manifesto entitled "Hacia una Federación de Cineclubs Proletarios" (Towards a Federation of Proletarian Film Clubs), published in the magazine in October 1933, though the federation never materialized. Piqueras' Cinestudio Nuestro Cinema launched its first session in December 1934 with Das blaue Licht / The Blue Light (Leni Reifenstahl, 1932), introduced by Antonio del Amo; the participation of the Hungarian communist Béla Balázs in its script and shooting presumably made it ideologically acceptable. Cinestudio Nuestro Cinema's programming followed the pattern of "proletarian film clubs," with their predilection for Soviet cinema, attempt to cater to a working-class public, irregular sessions, and ideological 


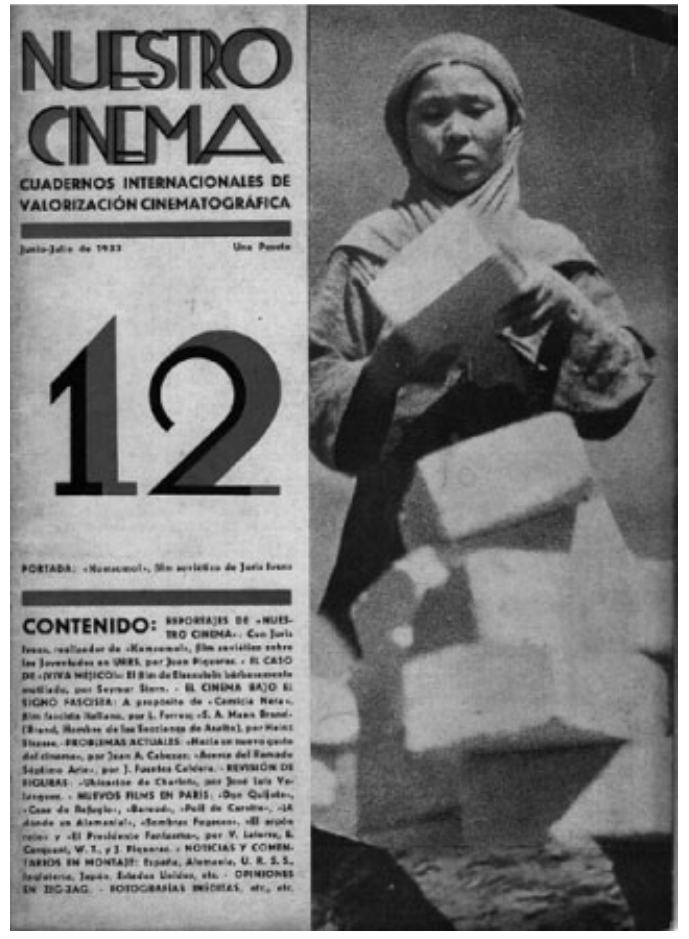

Figure 15.1 Nuestro Cinema (June-July 1933) featuring a still from Joris Ivens' Konsomolsk (1932). Private collection.

instrumentalization of screenings through discussion sessions (see Figure 15.1). Cine-Teatro Club, linked to the Spanish Communist Party's daily Mundo Obrero, screened Soviet films and exhibited Party documentaries (e.g., Primero de mayo en Madrid / 1st of May in Madrid). Student and white-collar unions also created their own film clubs. The Federación Universitaria Escolar (FUE; Federation of University Students) ran the Cineclub FUE, directed by biologist Carlos Velo and journalist Fernando G. Mantilla, holding its sessions in Urgoiti's Palacio de la Prensa from 1933. Also active in 1933 was the Cineclub de los Empleados y Banca y Bolsa (Bank and Stock Exchange Workers Film Club), which produced the film El despertar bancario / The Banks' Awakening, a history of the Bank and Stock Exchange Workers Union.

In 1934 the film club scene expanded as specific groups set up their own organizations: Cineclub de la Juventud Roja (Red Youth Film Club), Cine-Studio Lyceum Club Femenino (Women's Lyceum Club Film Studio), Centro Cultural Deportivo Obrero Avanti (Avanti Workers Cultural and Sports Center), Cineclub La Lucha (The Fight Film Club), Cineclub Trabajadores de la Distribución y Producción de Material Cinematográfico (Film Distribution and Production Workers Film Club), Cineclub de Trabajadores de Comercio (Shopworkers Film Club), Cineclub del 
Socorro Obrero Español (Spanish Workers Aid Film Club), Cineclub Frente Universitario (University Front Film Club), Cineclub del Socorro Obrero en el Cinema (Cinema Workers Aid Film Club), and Cineclub de la Biblioteca Circulante de Chamartín de la Rosa (Chamartín de la Rosa Lending Library Film Club), organized by the ubiquitous cineclubista Julio González Vázquez, who was linked to several "proletarian film clubs" and attracted Alberti and his fellow communist intellectual Wenceslao Roces to introduce its sessions.

The 1930s also saw the film club phenomenon spread throughout the country. Film clubs sprang up in Valencia, Seville, Toledo, Santander, Oviedo, and Cartagena. The Cine-Club Valencia held its first session on May 18, 1930, organized by Piqueras, while the Cine-Studio Popular de Valencia was linked to the communist magazine Nuestra Cultura, edited by the poster artist Josep Renau. The anarchists also took an interest in cinema, as seen in José Peirats' 1935 leaflet Lo que podría ser un cine social (Blueprint for a Social Cinema).

Fascism too paid attention to film, a communications medium to which Mussolini, Hitler, and Goebbels attached great importance. In December 1934, the Falangist Carlos Ruiz de la Fuente suggested to the Falange's founder, José Antonio Primo de Rivera, that they should use film as a propaganda tool, since Primo de Rivera was known to admire certain "social" films as conceived in Mussolini's Italy, as well as Henry Hathaway's colonial film Lives of a Bengal Lancer (1935). On February 23, 1935, the Film Club of the Sindicato Español Universitario (SUE; fascist Spanish University Students' Union), organized by Ruiz de la Fuente, held its first screening at Madrid's Cine Bilbao, at which it showed Camicie nera / Blackshirts (Giovacchino Forzano, 1933), described as "the Fascist Potemkin." Two months later, its second session screened the German film Morgenrot / Dawn (Gustav Ucicky, 1933), which extolled submarine warfare and heroic death.

After the Civil War, Valencia's Cineclub Mediterráneo, linked to Radio Mediterráneo, owned by the Falangist future film director, scriptwriter, and producer Vicente Escrivá, started to operate in late 1940. In Madrid in January 1941, the National Film Department created the government body Círculo Cinematográfico Español (CIRCE; Spanish Film Circle) to bring together film professionals and deal with their concerns; its film club was inaugurated in February with a screening of Ninotchka (Ernst Lubitsch, 1939). This state-run film club screened films banned by the censors, but the (also state-run) film magazine Primer Plano warned against attending its sessions out of idle curiosity rather than a thirst for knowledge. Again run by the state, the Círculo de Escritores Cinematográficos (CEC; Circle of Film Writers) founded its film club in Madrid in November 1945, holding 105 sessions through June 1951. 1945 also saw the creation of the Cineclub de Zaragoza (Zaragoza Film Club), founded by Eduardo Ducay, Manuel Rotellar, Antonio Serrano, and Orencio Ortega Frisón.

In November 1951, the Italian Cultural Institute in Madrid, which enjoyed diplomatic immunity, held its first Italian Film Week; a second followed in March 
1953. These film series would form a landmark in the history of Spanish cinema. Their screenings of Italian neo-realist films previously unknown in Spain made a huge impact on Juan Antonio Bardem, Luis García Berlanga, and other young Spanish filmmakers, sending their careers in new directions. In 1951, the French Institute in Barcelona opened its Cercle Lumière. Foreign cultural institutes, with private film screenings for members, provided a haven for Spanish cinephiles for the almost forty years of the dictatorship.

University film clubs took on a similar dissident political function. The SEU, a Falangist organization, as explained above, was under the Franco dictatorship the mandatory, sole university students' union, run by the state; as such, it had responsibility for cultural activities across the whole Spanish university system. Film clubs started to be organized within its framework from 1940. The Cineclub del SEU in Barcelona, run by José María Castellet, was created in 1949, and organized a lecture cycle in the same year. In the 1950s, the SEU film clubs would grow into a network with government backing but frequently infiltrated by dissident cinephiles who turned its branches into sites of ideological resistance to the regime, as had happened in fascist Italy. Competing with them were the film clubs run by the Catholic Church - such as Madrid's Cineclub Vinces (1952-8) - under the umbrella of Acción Católica, which used cinema as form of proselytizing. When, in April 1952, the Madrid Ateneo held the first Congreso Nacional de Cineclubs (National Congress of Film Clubs), twenty-six organizations attended.

At this time, non-Church film clubs depended on the SEU's Departamento Nacional de Actividades Culturales (National Cultural Activities Department); from 1954 the latter's national leader was the communist activist Manuel Rabanal Taylor. To give an idea of programming: in 1955 the Salamanca SEU film club screened fragments of Eisenstein's October and Pudovkin's Storm over Asia, while from February to May 1956 its Barcelona equivalent, run by Román Gubern, programmed three Soviet films: Vladimir Petrov's Thunderstorm (1934), Aleksandr Ptushko's The New Gulliver (1935), and Battleship Potemkin - the screening of the last film was banned by the civil governor.

One of the most active SEU film clubs was the one in Salamanca, launched in March 1953 by a group led by Basilio Martín Patino, which from 1955 to 1963 published the magazine Cinema Universitario. It was this group that in 1955 would hold the controversial Salamanca Conversations. The first issue of Cinema Universitario, dated January-March 1955, defended neo-realism as a model for Spanish cinema, going against Francoist cultural policy. This first issue published the call for the Conversaciones Cinematográficas Nacionales (National Cinema Conversations), as they were officially titled. Its second issue - October-December 1955, after the Conversations had taken place, and edited by Luciano G. Egido, Joaquín de Prada and José María Gutiérrez - defended the meeting against government criticism. In its fourth issue (December 1956), J. F. Aranda reclaimed Buñuel for Spain in his essay "Buñuel nacional" while the eleventh issue (March 1960) was devoted to Joris Ivens. Contributors to the magazine included Bardem, Berlanga, Carlos Saura, 
Ricardo Muñoz Suay, Ducay, Joaquín Jordà Gubern, Enrique Tierno Galván, and Mario Vargas Llosa. After its January-May 1963 issue, the magazine was banned. This was because of the hostile letter sent by Carlos Álvarez, a contributor to the magazine, to the censor and director of Filmoteca Nacional, Carlos Fernández Cuenca, commenting on the latter's criticisms of Orson Welles' Le Procès / The Trial (1962) and on the trial of the communist activist Julián Grimau, executed in April 1963 - an episode that led to Álvarez's own trial and imprisonment.

The call for the National Film Conversations was drafted jointly by the organizers of the SEU film club at Salamanca and the editorial team of the magazine Objetivo, affiliated to the clandestine Communist Party, in consultation with representatives of progressive Catholic sectors (such as José María Pérez Lozano) and of the critical wing of Falangism (such as Marcelo Arroita-Jáuregui). It criticized Spanish cinema for having abdicated its responsibility to be a "testigo de nuestro tiempo" (witness to our times), invoking the realist tradition of Spanish art and literature as a model for film. After obtaining government authorization, the encounter was held at Salamanca University from 14 to 19 May 1955, with the participation of Spanish film professionals and invited foreign speakers (Cesare Zavattini, Guido Aritarco, and Manoel de Oliveira; Georges Sadoul's attendance was not authorized). The papers coincided in their criticisms of Spanish cinema, asking for a more rational system of state production subsidies, distribution guarantees, a censorship code to replace the censors' current ad hoc mode of operating, the creation of a federation of film clubs, and an end to the monopoly of the state newsreel NO-DO. The critique formulated at Salamanca was summed up in Bardem's verdict that Spanish cinema was "políticamente ineficaz, socialmente falso, intelectualmente ínfimo, estéticamente nulo e industrialmente raquítico" (politically inept, socially hollow, intellectually vacuous, aesthetically worthless, and industrially stunted). The direct and indirect attacks on state control of Spanish cinema were accused in official quarters of being "subversive" but were supported by Objetivo and Cinema Universitario, and their reformist proposals were in large measure adopted by José María Garcìa Escudero (a participant in the Conversations) when in July 1962 he was appointed Director General of Film and Theater. But they were attacked by the radical left at the Primeras Jornadas Internacionales de Escuelas de Cinematografía (First International Film School Festival) at Sitges in 1967 (see the following section).

The Salamanca film club remained active but only in 1960 was it allowed to screen Rossellini's antifascist manifesto Roma, città aperta / Rome, Open City (1945). The second half of the 1950s saw a spectacular explosion of film clubs. In 1956, SEU film clubs were created in Seville and Pamplona (the latter an offshoot of the Zaragoza parent club). The magazine Cine-Club, the organ of SEU film clubs, started publication in May 1956, with fifteen issues through April 1958. This effervescence led the Ministry of Information and Tourism to issue an order of March 11, 1957 setting up a "Registro Oficial de Cine-Clubs" (State Register of Film Clubs); this was matched by the call for a Conference of Film Clubs in Madrid, to 
set up a federation to oversee their development and activities. But those film clubs linked to the Church refused to participate after a stormy conference in April of that year. On December 15, 1957, the Federación Española de Cineclubs (Spanish Federation of Film Clubs) was created, with José G. Maesso as president. Awareness of film clubs' social relevance lay behind the activities of the Cine-Club Monterols, housed in an Opus Dei residence in Barcelona, founded in 1951 but from 1957 launching an intensive program of activities, geared to the aesthetic concerns of the magazine Cahiers du Cinéma. In May 1960, this film club launched the magazine Documentos Cinematográficos with contributions from Jorge Grau, José Luis Guarner, and Javier Coma, paying particular attention to the financial and industrial aspects of cinema. It ceased publication in 1963.

By 1961 the Federation had eighty-six member film clubs. A government order of July 1963 authorized them to import foreign films. Another order of January 12, 1967 authorized "salas de arte y ensayo" (exclusive theaters licensed to screen arthouse cinema) in cities with over fifty thousand inhabitants; their specialist programming produced strong competition for the film club network. In 1969 there were 244 federated film clubs. After Franco's death in 1975 and the abolition of censorship in November 1977 (when Buñuel's 1961 film Viridiana was finally premiered in Spain), things changed radically. 1977 saw the creation of the Confederación de Cineclubs del Estado Español (Confederation of Film Clubs of the Spanish State), which recognized the new political decentralization. But the dissident political agenda that had been such an important offshoot of film clubs under the dictatorship disappeared, at a time when television, regional filmotecas, and soon the appearance of domestic video players took over many of the functions that film clubs had previously fulfilled.

\section{Film Festivals (Román Gubern)}

The first film festivals in Spain were inaugurated during the Franco dictatorship, when - like film clubs, as we have seen - they had a significant political function. Initially designed to benefit the regime, they pushed the boundaries of what was or was not officially regarded as permissible, in some cases becoming spaces of more-or-less open dissidence.

After the United Nations announced its diplomatic boycott of the dictatorship on February 9, 1946, the government tried to break its international isolation by reactivating its relations with the countries of Spanish America, with the aim of integrating them into one big Hispanic political and cultural family (see Chapter 2). Already in November 1940 the regime had created the Consejo de la Hispanidad (Council of Hispanicity), one of whose first tasks was to produce the film Raza / Race (1942), a patriotic epic based on a screenplay by Franco and directed by the Falangist José Luis Sáenz de Heredia. In accordance with this strategy, the Sindicato 
Nacional del Espectáculo (state-run National Entertainment Union) organized the first Certamen Cinematográfico Hispanoamericano (Spanish American Film Competition) in Madrid from June 27 to July 4, 1948, with the participation of Spain, Argentina, Mexico (which did not have diplomatic relations with Spain), Cuba, and a representative from Colombia. Although its aim was to encourage coproductions and commercial exchange in the field of cinema, it also functioned as a film festival, with films being screened from the participating countries; a jury diplomatically awarded the top three prizes to the Spanish film Locura de amor / The Mad Queen (Juan de Orduña, 1948), the Argentine Dios se lo pague / God Reward You (Luis César Amadori, 1948), and the Mexican Río escondido / Hidden River (Emilio Fernández, 1948), respectively. The plans to make this competition an ongoing event did not come to fruition but it did lead to some joint ventures (see "The Latin American Connection" in Chapter 2).

This conception of the film festival as a window onto cultural exchange with the outside world was not taken up again until the 1950s. The Semana Internacional de Cine de San Sebastián (San Sebastián International Film Week) was inaugurated on September 21, 1953 and promoted by local commercial and tourist organizations. Authorization was given to screen the occasional film banned from commercial release, such as Jacques Becker's Casque d'or / Golden Marie (1951), but the awards for Best Film, Best Director, and Best Leading Actor went to Rafael Gil's Catholic propaganda film La guerra de Dios / I Was a Parish Priest (1953). The following year the festival changed its name to Festival Internacional de Cine de San Sebastián (San Sebastián International Film Festival). The censorship board took a permissive line in authorizing films to be screened at the festival. Thus, in July 1958 the award for Best Film was given to Tadeusz Chmielewski's Ewa chce spac / Eva quiere dormir / Eva Wants to Sleep, from communist Poland, at a time when films from Eastern Europe could not be exhibited in Spain. Further, in July 1960 the Best Film award went to the Czech director Jiri Weiss' Romeo, Julia a tma / Romeo, Julieta y las tinieblas / Romeo, Juliet and Darkness. It was not until December 1965 that the Ministry of Information and Tourism, responsible for film censorship, would normalize the import of Soviet films and the export of Spanish films to the USSR. The San Sebastián Film Festival participated in the promotion of the New Spanish Cinema encouraged by the "liberalizing" policies of José María García Escudero as General Director of Film and Theater since 1962. Accordingly, it awarded the Concha de Plata (second prize) to Manuel Summers' Del rosa ... al amarillo / From Pink ... to Yellow in 1963 and to Basilio Martín Patino's Nueve cartas a Berta / Nine Letters to Bertha in 1966, and the Best Director award to Miguel Picazo's La tía Tula / Aunt Tula in 1964, as well as awarding the Concha de Oro (top prize) to Víctor Erice's El espiritu de la colmena / The Spirit of the Beehive in 1973, and to José Luis Borau's Furtivos / Poachers in 1975 (two months before Franco's death).

After the end of the dictatorship, the San Sebastián Film Festival, established as Spain's most influential film competition, continued to operate as a commercial platform for national cinema, thanks to the awards given to Jaime Chávarri's $A$ un 
dios desconocido / To an Unknown God (1977), Jaime Camino’s La vieja memoria / The Old Memory (1977), Manuel Gutiérrez Aragón’s Sonámbulos / Sleepwalkers (1978), Gonzalo Herralde's El asesino de Pedralbes / The Murder of Pedralbes (1979), Carlos Saura's Mamá cumple cien años / Mama turns 100 (1979), Imanol Uribe’s El proceso de Burgos / The Burgos Trial (1980), and Gutiérerez Aragón’s Demonios en el jardin / Demons in the Garden (1982), among other Spanish films.

In March 1956, the Catholic-inspired Primera Semana de Cine Religioso y de Valores Morales (First Religious and Moral Cinema Week) was held in Valladolid. The censors adopted a tolerant line toward this festival too, with its third edition of March 1958 awarding first prize to Jules Dassin's Celui qui doit mourir / He Who Must Die (1957), based on a novel by Nikos Kazantzakis; the film had been banned from general release in Spain. In 1960, this festival - which from that year regularly programmed films by Ingmar Bergman - was subdivided into two separate sections, "Religious Values" and "Human Values," which allowed it to broaden its scope and to give a special award to Manuel Summers' documentary Juguetes rotos / Broken Toys (1966). In 1972 it abandoned its initial thematic focus, changing its name to Seminci (Semana Internacional de Cine (International Film Week)). Fernando Lara, its director from 1983 to 2004, built the festival up into a prestige event, thanks to its rigorous selection criteria. Seminci also published monographic studies on Edgar Neville (1982), Luis Marquina (1983), and Carlos Serrano de Osma (1983), all by Julio Pérez Perucha, which helped to revive interest in the work of these neglected directors. When Fernando Lara had to give up directing Seminci, on receiving a government appointment as director of the Instituto de la Cinematografía y de las Artes Audiovisuales (ICAA; Institute of Film and Audiovisual Media), the festival entered into a period of instability.

September 1959 saw the beginning of the Semana Internacional de Cine de Color de Barcelona (Barcelona International Color Film Week), sponsored by the Cineclub Monterols, affiliated to an Opus Dei residence in the city (see the previous section). From 1975 it changed its name to Semana Internacional de Cine de Barcelona (Barcelona International Film Week), under the directorship of film critic José Luis Guarner. The political turbulence of the transition to democracy impacted on this Barcelona film festival, with the legal sequestration in October 1978 of Pier Paolo Pasolini's Salo o le 120 giornate di Sodoma / Salo, or the 120 Days of Sodom, thanks to a denunciation lodged with a local police court by a private citizen. In July 1987 it became the Primer Festival de Cine de Barcelona (First Barcelona Film Festival), in that year giving the awards for Best Film, Best Script, and Best Director to Agustí's Villaronga's Tras el cristal / In a Glass Cage; it subsequently declined.

In October 1959, the Certamen Internacional de Cine Documental Americano y Filipino (International American and Filipino Documentary Film Competition) opened in Bilbao, later becoming the Certamen Internacional de Cine Documental y Cortometraje de Bilbao (Bilbao International Documentary and Shorts Competition). From 1979 to 1981 it pioneered screenings of films made during the 
Civil War, some of which had previously been shown only at the Filmoteca Nacional in Madrid, as well as publishing brochures on the topic.

The Primeras Jornadas Internacionales de Escuelas de Cinematografía (First International Film School Festival) took place in Sitges from 1 to 6 October 1967, screening work by film schools from a range of cities worldwide, including Moscow, Prague, and some Asian countries. During the discussion time, a group of radical Spanish filmmakers - Manuel Revuelta, Antonio Artero, Joaquín Jordà, and Julián Marcos - read out a manifesto, which was approved at the closing assesmbly. This demanded the abolition of the Sindicato Nacional del Espectáculo (state-run National Entertainment Union), censorship, government subsidies, and all control mechanisms, in strident opposition to the cautious "bourgeois reformism" of the May 1955 Salamanca Conversations. The police broke into the closing dinner, making several arrests, and the following year the festival was replaced with the more innocuous Festival Internacional de Cine Fantástico de Sitges (Sitges International Fantastic Cinema Festival), first held in September 1968. This festival has consolidated its reputation as a specialist competition. The revolutionary 1967 Sitges Manifesto became a reference point for critical sectors (mainly Maoist) to the left of the Communist Party, such as the "Marta Hernández" collective and the brothers Carlos and David Pérez Merinero (authors of the 1975 book Cine y control (Cinema and Control)).

In November 1969, the Primera Semana de Cine de Autor de Benalmádena (Benalmádena First Auteur Cinema Week), directed by Julio Diamante, was held in Málaga province. This competition, whose prizes were awarded by popular vote, offered rigorous programming, screening cinemas previously unknown in Spain (Chinese, Palestinian, Chicano, etc.), but suffered a police raid leading to arrests in 1970; it was held for the last time in April 1989.

Effectively, in the dictatorship's twilight years, certain film festivals and magazines became sites of cultural and political resistance, fighting for an alternative cinema culture to that espoused by the regime. As seen in Chapter 2, international film festivals also provided a haven for certain dissident Spanish filmmakers. Spain participated in the Cannes Film Festival for the first time in April 1953, with Neville's Duende y misterio del flamenco / Flamenco and Berlanga's iBienvenido Mister Marshall! / Welcome Mr. Marshall! The latter won a prize and generated a polemic (Edward G. Robinson, serving on the jury, demanded that an "anti-American" shot be cut), which led Franco to ask to see the film. In May 1961, Cannes awarded the Palme d'Or to Luis Buñuel's Viridiana but, as previously noted, the film was banned in Spain and would not be shown there until April 1977. The Venice Biennale of September 1956 gave the FIPRESCI prize (awarded by the International Critics Federation) to Calle Mayor / Main Street by Bardem, a communist activist who had been arrested by the Francoist police while shooting the film. And the same festival, in September 1960, awarded the same prize to the Italian director Marco Ferreri's Spanish production El cochecito / The Motorized Wheelchair, which was mutilated by the Spanish censors, leading to cancellation of the director's Spanish 
residence permit. This kind of complicity by international festival juries led the Ministry of Information and Tourism to issue an order on January 31, 1964 requiring Spanish producers to seek prior government authorization to submit their films to film festivals.

Chapter 2 has shown how Carlos Saura was one of the dissident directors who most benefitted from this international complicity. Not only did his film La caza / The Hunt (1965), whose script had suffered significant cuts at the censors' hands, win the Silver Bear for Best Director at the Berlin Film Festival of July 1966, but in July 1968 the same festival awarded a prize to his 1967 film Peppermint frappé. Although his El jardin de las delicias / The Garden of Delights (1970) was banned for seven months, it was authorized to enter the New York Film Festival; as a result of its enthusiastic reception there, it was authorized for release with three major cuts. In addition, Saura's La prima Angélica / Cousin Angelica (1974) received the Jury Special Award at Cannes in 1974, before its screening produced fascist protests in Spain, leading to the sacking of Pío Cabanillas as Minister of Information for having authorized the film's release.

General Franco's death in November 1975 marked the start of a new permissiveness in cinema, which impacted on festival programming. December 1975 saw the inauguration of the Primera Semana Internacional de Cine Iberoamericano de Huelva (Huelva First International Ibero-American Cinema Week - later renamed the Festival de Cine Iberoamericano de Huelva (Huelva Ibero-American Film Festival) - which the following year paid tribute to Buñuel, who travelled to Huelva for the event.

From 1977, when the first general elections since the 1930s were held, the climate of democratic euphoria produced an explosion in the number of festivals (though many would prove short-lived) at a time when cinema attendance was declining thanks to competition from television. In January 1980, the Primera Muestra de Cine Imaginario y Ciencia Ficción (IMAGFIC; First Festival of Imaginary and Science Fiction Film) opened in Madrid, continuing successfully until 1993. November 1980 saw the Primera Mostra de Valencia: Cinema del Mediterrani (First Valencia Mediterranean Cinema Festival), still active today.

Since the early 1990s, there has been a proliferation in Spain of specialist festivals, even microfestivals, focusing on Spanish cinema (Málaga), Latin American cinema (Lleida), African cinema (Barcelona), European cinema (Seville), comedy (Alfàs del $\mathrm{Pi}$, Valencia), documentary (Barcelona, Pamplona, and Madrid), sports films (Seville), horror films (San Sebastián), youth cinema (Valencia), women filmmakers (Barcelona), gay and lesbian cinema (Barcelona), cinema of the south (Granada), erotic cinema (Barcelona, Madrid, and Seville), and so on. In 2009, a total of 233 film festivals were held in Spain. This illustrates a concern with niche marketing that is partly commercial and partly educative, and also a desire on the part of the various local communities to gain cultural capital and media attention. At a time when there are concerns about the future of cinema-going in Spain, the way forward may be intensive, specialist programming of this kind. 


\section{Film Archives (Román Gubern)}

What follows is a story of loss, thanks to a late start, offset by a proliferation of activity in Spain's present-day autonomous communities. The result is a conception of national heritage in which the cultural diversity of Spain's regions plays a major role, while costly activities such as recuperation and restoration remain largely centralized in the national archives in Madrid, which are integrated into the central state apparatus.

The first national film archive conceived on modern cultural and technical lines was that of Sweden, founded in 1933, in a country whose film industry had blossomed economically and artistically in the 1920s. In the United States, the MoMA Film Library was created in 1935. At that time, the position of the Spanish film industry was precarious, while its productions enjoyed little cultural capital and attracted little government interest. Consequently, Spain was slow to organize an efficient storehouse to conserve its audiovisual heritage. The Spanish National Film Archives (Filmoteca Nacional) in Madrid were created by decree on February 13, 1953 as a state body within the Ministry of Information and Tourism, with the film historian and critic Carlos Fernández Cuenca serving as director until 1966. A year later, on April 2, 1954, the Cinemateca Educativa Nacional (National Educational Film Archive) was also set up in Madrid, within the Ministry of Education, specializing in pedagogical documentaries. Both initiatives were part of the modernizing cultural agenda that succeeded the prolonged period of political isolationism (autarky) from the Civil War's end in 1939 to the lifting of the United Nations' diplomatic boycott on the Franco regime in November 1950. By the time the Filmoteca Nacional was created, most silent cinema and films of the 1930s had definitively vanished from circulation and could not easily be recovered. The Filmoteca's founding collection came chiefly from the film stock that had been impounded by the Francoist authorities on military victory in 1939 (mainly Republican and Soviet films, plus wartime newsreels and documentaries) and that had survived the fire on August 16, 1945 at Madrid's Laboratorios Cinematiraje Riera, where this confiscated material was stored. The date of this fire, which destroyed the cinematic memory of the Republic and the war, and whose causes were never clarified, is politically suspicious since it coincides with the end of World War II, when it was felt that the Franco regime was likely to suffer reprisals because of its close political relations with the Axis powers (films from the Republican zone were kept in red tins and those from the Nationalist zone in blue tins). This fire plus four others at major laboratories make it likely that little more than ten percent of pre-1936 Spanish cinema has been conserved. A contributing factor to this devastation is the paradoxical "success syndrome," whereby the greater and more immediate a film's success, the more likely it is to suffer damage as a result of overuse of the negative to make copies. Another result of success is the generation of remakes, leading to neglect of the original version. Fernández Cuenca allowed occasional exhibition of films from the Filmoteca's archives 
(usually private screenings at film clubs), sometimes introduced by himself. These screenings helped to make the material deterioration irreversible, at a time when no professional preservation work was undertaken.

On his appointment as Director General of Film and Theater in July 1962, José María García Escudero encouraged an active program of activities at the Filmoteca. In 1963 it started weekly public screenings in Madrid and Barcelona, sometimes accompanied by the publication of monographs by Carlos Fernández Cuenca. The result, from 1963 on, was a series of studies of the work of Georges Méliès, E. A. Dupont, F. W. Murnau, Erich von Stroheim, Carl Dreyer, Robert Flaherty, Sergei Eisenstein, Jean Renoir, Florián Rey (cowritten with Florentino Soria), and the French New Wave. A decree of February 20, 1964 required all producers and distributors to deposit a copy of their films with Filmoteca Nacional if they had received some kind official credit or subsidy, but in practice the copies sent to the Filmoteca were often incomplete or defective (e.g., black-and-white copies of color films, or copies that included rejected footage).

After García Escudero was sacked in November 1967, the Filmoteca's activities declined until, on November 17, 1970, the Ministry of Information and Tourism reorganized it, naming Florentino Soria as director. After the institution of democracy, an order dated May 20, 1980 transferred to the Filmoteca the archives of the state newsreel NO-DO. In February 1982 the archives' name was changed to Filmoteca Española, constituted as an autonomous institution affiliated with the Ministry of Culture, with Berlanga briefly serving as its director. During the 1980s, which saw the start of a program of recovery and restoration of films, the Filmoteca was directed from April 1983 by Juan Antonio Pérez Millán and from October 1986 by Miguel Marías, who was replaced in October 1989 by the current director, José María Prado. In February 1989, thanks to the Madrid City Council's sponsorship, the Cine Doré - one of Madrid's oldest cinemas - was completely refurbished and inaugurated as the venue for Filmoteca Española's regular screenings. But the Filmoteca did not attain the planned administrative goal of operational autonomy; in the end its legal status was formalized as that of a general subdirectorate of the Institute of Film and Audiovisual Media (created in January 1985), within the Ministry of Culture.

The consolidation of democracy and the creation of autonomous regional governments allowed the gradual emergence of regional film archives, though the extent of their holdings and activities would vary greatly. The Basque Filmoteca (Euskadiko Filmategia) was established in May 1978, in San Sebastián, as a private initiative linked to the Partido Nacionalista Vasco (PNV; Basque Nationalist Party), legally constituted as a cultural association. Peio Aldazabal was appointed its first director. On January 1, 1981, at the Primeros Encuentros de Cine de Autor e de Arte i Ensaio (First Symposium on Auteur and Arthouse Cinema) in Vigo, the Filmoteca do Pobo Galego (Film Archives of the Galician People) was created, housed in Vigo's Municipal Cultural Center, but it proved short-lived. In Barcelona, a city with a major history of activity in the field of cinema, the Filmoteca of the 
Generalitat de Catalunya (Catalan Autonomous Government) was instituted on June 1, 1981 under a decree transferring the operation of cultural services from the state to the Generalitat. Its first directors were Ramón Herreros and Ramón Font. Also in June 1981, Zaragoza City Council voted to institute the Filmoteca of Zaragoza, which would be headed by the historian Manuel Rotellar, with public programming starting on February 4, 1982. The Filmoteca Canaria, in Las Palmas de Gran Canaria, was set up on November 3, 1984 by an order of the Cultural Office of the Autonomous Government of the Canaries; this was followed on November 22 by the creation of the Filmoteca de Galicia by the Galician Autonomous Government - with a library, video library, and photo library - based in A Coruña. In February 1985, the Valencian Government established the Filmoteca de la Generalitat Valenciana, under the directorship of Muñoz Suay, which from May 1989 would publish the film journal Archivos de la Filmoteca (see the final section of this chapter). March 1987 saw the creation of the Filmoteca Regional de Murcia, effectively operational since January 1986. In December 1987, the Junta de Andalucía instituted the Filmoteca de Andalucía, based in Córdoba. In October 1989 the Centro Galego de Artes da Imaxe (Galician Center for the Visual Arts) was created in Santiago de Compostela; it functioned as a film archive with regular screenings. The Filmoteca de Castilla y León was established in January 1991 in Salamanca and opened in March with Juan Antonio Pérez Millán as director. And, on May 11, 1999 the Archivo del Sonido y de la Imagen de Mallorca (Audiovisual Archive of Majorca) was inaugurated, in Palma de Mallorca, directed by Margalida Alberti under the Consejo de Mallorca's Department of Culture and Heritage; this would become the future Filmoteca de Mallorca.

Not all the film archives listed here have been equally active. Although Filmoteca Española remains the most important because of the size of its holdings - some 34000 items - and level of activities, the Filmotecas of Valencia and Catalonia (the latter holding an important collection of films by Segundo de Chomón) have also been extremely dynamic, as well as publishing major book series. The regional archives have had to rely on the technical services of Filmoteca Española for the preservation and restoration of their holdings. Filmoteca Española has pioneered the recuperation and restoration of historical material since the 1980s, thanks to the efforts of competent professionals such as Alfonso del Amo, Luciano Berriatúa, and Ferran Alberich (see the next section by Alberich). A major contribution to recuperation has been Filmoteca Española's acquisition of the Archivo Luis Buñuel from the filmmaker's family. Alfonso del Amo was responsible for the fundamental catalog of Spanish Civil War cinema (Del Amo 1996), published by Filmoteca Española as the first of an important collection of reference works, including inventories of Spanish directors of photography (Llinás 1989), art directors (Gorostiza 1997), screenwriters (Riambau and Torreiro 1998), and producers (Riambau and Torreiro 2008). These volumes, like those published jointly with the San Sebastián Film Festival, have made a notable contribution to the bibliography on cinema in Spain. 


\section{Film Preservation and Restoration (Ferran Alberich)}

The expansion of film archives in the last few decades, discussed in the previous section, has hugely increased the availability to the public of Spanish films, through screenings, video libraries, and viewing facilities. However, it is not enough to build up film holdings; conservation needs to be supplemented by expert preservation and restoration work. The weakness of the Spanish film industry has been a major problem here. In the past, lack of continuity of production companies, with ownership of exhibition rights changing hands, meant that responsibility for the conservation of film stock fell on film laboratories, which became producers' de facto archives. The appearance of new forms of commercialization - first television broadcasting, then analog and digital home video - raised hopes that, given the new business opportunities, the holders of the rights would take an interest in preservation, but that did not happen. In Spain, television broadcast of films did not become regular until well into the 1960s. For these transmissions, as well as for the first video transfers, exhibition copies were used; the standard practice, when the copy to be broadcast showed signs of wear (scratches, tears, etc.), was to cut the whole sequence - the effect of this on the subsequent study of many films has been catastrophic. Since Spanish films were mostly made for domestic consumption rather than export, the number of copies made for exhibition was relatively small; consequently, it was not economically viable for the producer to make intermediary copies, with the result that all copies were made from the original negative. As noted in the previous section, original negatives of successful films have particularly suffered, since more copies were made.

Given this situation, in Spain responsibility for preservation and restoration work has been taken by the public sector: that is, film archives under central state, autonomous government, or municipal control (in practice, mostly the state archives in Madrid). When in the mid-1980s the first studies were made of the state of preservation of films in Spanish archives, a complicated picture emerged. As noted in the previous section, by the time the first public archive, Filmoteca Nacional, was created in 1953, practically the whole of silent cinema had been lost, and fires at the Cinematiraje Riera laboratories in 1945 and the Madrid Film Laboratories in 1951 had had devastating effects. The Cinematiraje Riera laboratories had housed all the films produced during the Civil War in both Republican and Nationalist zones as well as a large proportion of those produced from 1931 to 1936 under the Republic - that is, virtually the whole of early Spanish sound cinema. The Madrid Film laboratories had housed the majority of original negatives for films made in the years immediately following the Civil War. In July 1953, the Ministry of the Interior issued an order banning the transport and handling of inflammable film material. This aggravated production companies' neglect of film negatives, which were literally abandoned to their fate in warehouses. Many Spanish producers destroyed the inflammable negatives and copies of their films 
without previously copying them to a non-flammable film base. In sum, it is fair to say that original negatives of almost the entirety of Spanish films made before 1953 have been lost. The best that film restorers can expect is to work with duplicate materials, almost always exhibition copies, and often $16 \mathrm{~mm}$ copies that do not match the originals (both because of the different aspect ratio and because of the differences in photographic quality).

What can be considered the first state ruling on the conservation of the national cinema heritage came in 1964, as part of José María García Escudero’s package of cinema reforms as General Director of Cinema and Theater. García Escudero's ruling requiring producers and distributors to deposit with the Filmoteca Nacional a copy of all films for which they had obtained state support did not solve the problem, however. As we now know, the existence of a positive copy of a color film negative does not in itself guarantee that the film will have survived in good condition, since the quality of duplication masters and conservation prints, positive and negative copies, CRI (color reversal intermediate) prints, camera negatives, and so on is very different from that of exhibition prints, which are not expected to have a working life of more than a few years. The color prints held by the Filmoteca in compliance with the 1964 legal deposit requirements are mostly badly deteriorated since, in addition to the irregularities mentioned in the previous section, a high proportion were used exhibition copies. It was only in the 1990s that the legislation on legal deposit was addressed, requiring producers to deposit conservation prints, production of which is subsidized by the state.

The chief preservation issue today is the transfer of acetate material to polyester, which is much more stable; this process has not yet begun to be addressed, since so far acetate degradation has not become a significant problem at the Madrid Filmoteca, which has by far the largest holdings of Spanish film stock. It is, however, an appreciable problem at the Barcelona and Valencia film archives, which have a much higher humidity level. The new film archives created after the return to democracy in 1975 , under autonomous government or municipal control, plus the many other institutions that today bear the name filmoteca, in practice do not have a conservation function but serve as exhibition venues for films that would not otherwise be screened. Since no Spanish film archives have their own laboratories, preservation and restoration work that requires the production of a new print - practically all of it - has to be undertaken off-site in private film laboratories. In Spain, since the introduction of sound cinema these have existed only in Madrid and Barcelona; consequently, the Madrid and Barcelona Filmotecas are the most active in the fields of preservation and restoration.

What could be seen as the earliest restoration work in Spain was undertaken at the Filmoteca Nacional in the late 1950s and 1960s. It involved transferring to acetate some surviving copies of silent films, which was done without prior inspection. The results were defective, since the shrinkage of the original materials resulted in an incorrect relationship between the perforations and the image. In keeping with widely accepted practice in film archives of the time, when nitrate 
was considered a dangerous substance, the originals were destroyed after the transfer to acetate, which means that this restoration work cannot be redone again today, under better conditions. In 1992, Filmoteca Española (as it was renamed in 1982) made a valiant effort to recover one of these films - Currito de la Cruz / Currito of the Cross (Alejandro Pérez Lugín, 1926) - which was restored by the director of photography, Juan Mariné, by selecting the stills that had retained the most detail and repeating them in place of those where most of the image had been lost. The result allows the film to be screened with spectators being able to follow the story, but the movement on screen does not flow as smoothly as would have been the case with the original.

After the early attempts of the late 1950s and 1960s, there was a hiatus until restoration work was resumed in the 1980s, again at Filmoteca Española. While studying F. W. Murnau's Nosferatu (1922), the filmmaker Luciano Berriatúa found in the copy held in Madrid a shot that was not in the copies in any other archive (he would complete the restoration of Nosferatu in 2006). This discovery awoke new interest in Filmoteca Española's holdings, triggering further investigation by Berriatúa and others. The resulting research made it possible to embark on the restoration of Lorenzo Llobet Gràcia's Vida en sombras / Life in Shadows (1948) previously unknown to critics and the public. When the restored copy was screened in 1983, it was hailed as a classic of Spanish cinema. This success marked the start of concerted film restoration work in Spain.

Although there has not been a coordinated plan for restoration work across the various film archives, there have been productive collaborations in the form of the exchange of materials or information. These collaborations have led to the restoration of films such as Frivolinas / Bagatelle (Arturo Carballo, 1926), Un chien andalou (Buñuel), La aldea maldita / The Cursed Village (Florián Rey, 1930), La verbena de la Paloma / Festival of the Virgin of the Dove (Benito Perojo, 1935), Carne de fieras / Food for the Lions (Armand Guerra, 1936; see Alberich 1993), Rojo y negro / Red and Black (Carlos Arévalo, 1942), Don Juan Tenorio (Alejandro Perla, 1952, with costumes and sets by Dalí), and Mañana / Tomorrow (José María Nunes, 1957). A particularly interesting case was the restoration of the original version of Raza (José Luis Sáenz de Heredia), which revealed how political censorship under the early Franco dictatorship affected even films exalting the regime. The film, shot in 1941 and released in early 1942, was produced by the Consejo de la Hispanidad (Council of Hispanicity), a Spanish state body, based on a screenplay written under a pseudonym by General Franco himself. After the defeat of fascism in 1945, it was deemed appropriate to produce a new version, modifying some dialogues (thereby stressing communism as the enemy) and suppressing the fascist salutes, the references to the US military as Spain's enemy in the 1898 Spanish-American War, and the hostile remarks against parliamentary democracy (see Figure 15.2). The remake was released in the summer of 1950, at the height of Spain's political and economic overtures to the United States, with the revised title Espiritu de una raza / Spirit of a Race. Copies of the original version were destroyed in an attempt to 


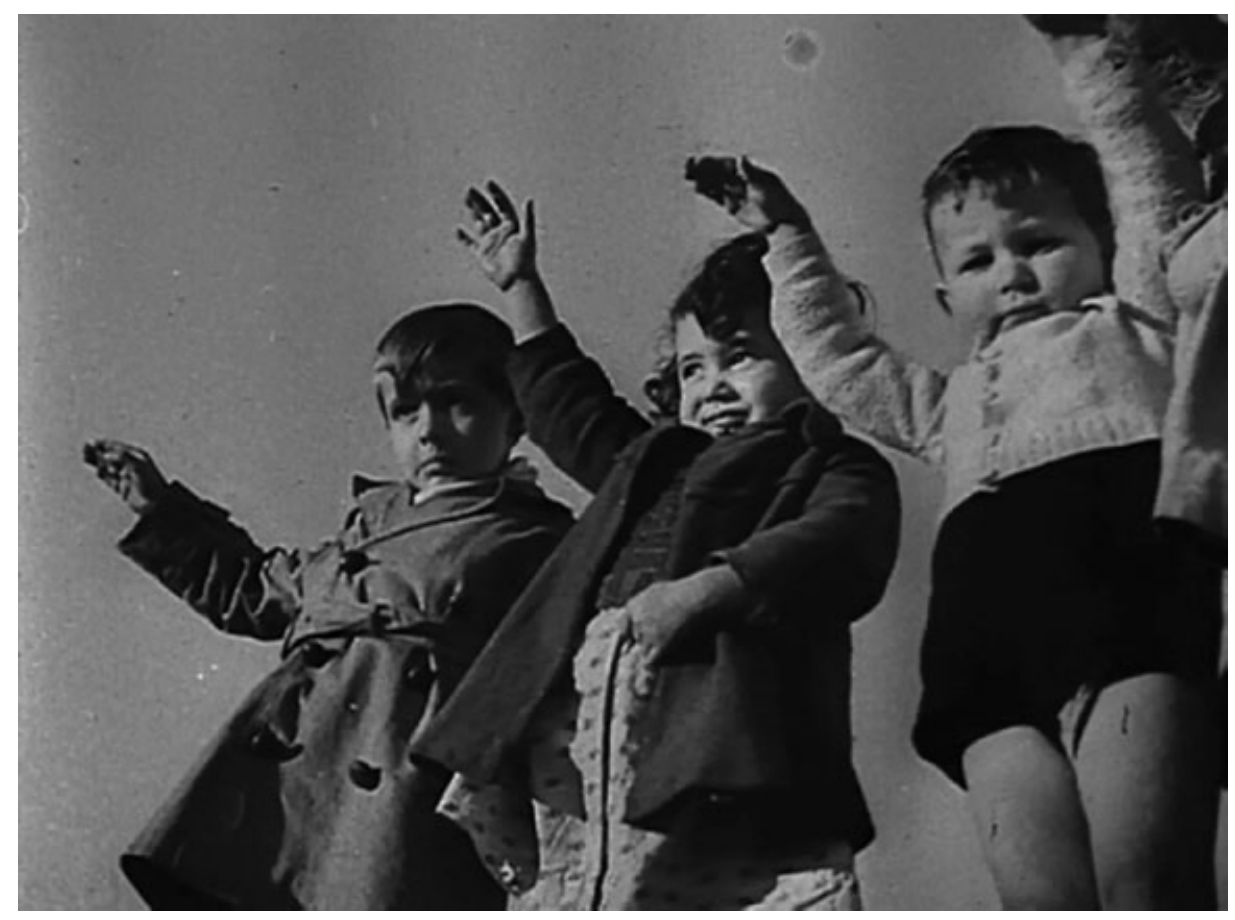

Figure 15.2 Children giving the fascist salute in the original version of Raza (José Luis Sáenz de Heredia, 1942; prod. Consejo de la Hispanidad), excised in the 1950 bowdlerized version. The original version was recently restored by Ferran Alberich for Filmoteca Española.

airbrush the early Franco regime's pro-fascist stance out of its film propaganda. After the fall of the Berlin Wall in 1989, when East and West German film archives were merged, a positive print of the original 1942 version was found in the former UFA archives in East Berlin. Thanks to collaboration between the Bundesarchiv and Filmoteca Española, the original version could be restored, revealing the exact changes to the original and thus providing an insight into Spain's repositioning of itself in the new Cold War climate after World War II (Alberich 1997).

The restoration work described so far was carried out by public-sector organizations. But there has also been some recent restoration work by the private sector. Most notable is that undertaken by the production company El Deseo of Pedro Almodóvar's early films, and by the producer Elías Querejeta, who restored the original negative of Víctor Erice's El espiritu de la colmena / Sprit of the Beehive (1973) - all damaged as a result of the previously mentioned "success syndrome." It should be noted that, with the new policy of state subsidies to make conservation prints, most recent Spanish films have been conserved in an appropriate form. The outstanding problem remains, though, of how to fund the restoration of cinema from earlier periods, whether on a nitrate or acetate film base. But there is also the challenge of how cinema-increasingly in digital format - will be preserved in the future. The only method currently known 
for ensuring the survival of digital copies deposited in archives is for them to be recopied periodically to new formats, since the durability of digital material is still unclear.

\section{Film Magazines from the 1930s to the 1960s (Román Gubern)}

This section covers film magazines in two politically charged periods: the 1930s, under the Second Spanish Republic, and the 1940s to the 1960s, under the Franco dictatorship. In both periods, film magazines staged ideological debates that went well beyond cinema as such, with film conceived not only as an art or as entertainment but also as a site of struggle between conflicting worldviews.

With the proclamation of the Republic in April 1931, there was an explosion of new film magazines, filling the gap left by the disappearance of the notable Madrid weekly La Pantalla (November 1927-August 1929). New titles in Madrid were Supercine (1932), Cinema (1932), Cinema Sparta (1932, financed by Ricardo Urgoiti's production company Filmófono), Cinegramas (1934), Crítica Cinematográfica (1934), Madrid Cinema (1934), Guirigay (1935), Gran Film (1935, directed by Rafael Gil), and Cine Star (1935). Barcelona saw the appearance of Cine y Hogar (1931), Cinema Amateur (1932), Filmópolis (1933), Cine-Art (1934, founded by Antonio Momplet), Cine Farsa (1934), Proyector (1935), Película (1935), and Última Hora (1935). New magazines in Seville were Altavoz (1934) and Andalucía Films (1935).

The most singular magazine was Nuestro Cinema, founded by the Valencian Juan Piqueras, a member of the Communist Party who had settled in Paris in May 1930. From Paris he contributed to Spanish newspapers and magazines such as La Gaceta Literaria, El Sol, Mundo Obrero, and Popular Film, and selected films for the distributor Filmófono and its film club Proa-Filmófono (see the section on film clubs earlier in this chapter). Nuestro Cinema (Paris and Madrid, June 1932-August 1935) was codirected by Piqueras in Paris and Antonio del Amo in Madrid. It established Soviet cinema as the model of "proletarian cinema" and was the only communist film magazine of the time in Western Europe. Its thirteenth issue (October 1933) marked the end of its first period. It resumed publication in January 1935, when it toned down its revolutionary rhetoric in accordance with the Komintern's new strategy of creating cross-class Popular Fronts. The magazine avoided cover photos promoting the star system, instead showing stills from documentary or Soviet cinema. It featured articles praising these cinematic forms by writers such as Eisenstein, I. Anissimov, Karl Radek, Léon Moussinac, Arconada, and Ramón J. Sender. In October 1933 it published a manifesto of the Association of Friends of Nuestro Cinema, with twenty-eight signatures including Arconada, Sender, Alberti, María Teresa León, and Emilio Prados. The February 1935 issue included an interview with Luis Buñuel by José Castellón Díaz and a review of the former's documentary Las Hurdes / Land without Bread by Arconada. Its last number featured a survey of Soviet cinema, with strongly favorable responses by Sender, Francisco Ayala, 


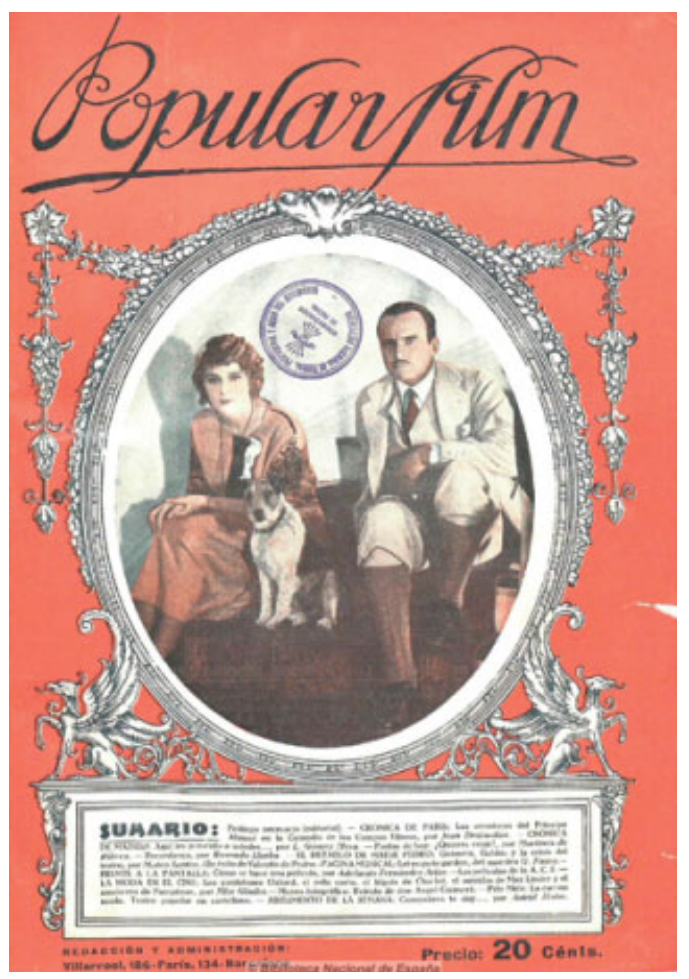

Figure 15.3 The first issue of Popular Film (August 1926). Private collection.

Antonio Espina, Benjamin Jarnés, and Federico García Lorca. (For Nuestro Cinema's attempt to set up a federation of proletarian film clubs and for its own film club Cinestudio Nuestro Cinema, see this chapter's earlier section on film clubs.) Piqueras was shot by fascists in Palencia in July 1936 at the start of the Civil War.

The most influential magazines of the 1930s were Popular Film and Cinegramas. Directed by the anarchist Mateo Santos, the weekly Popular Film was published in Barcelona from August 1926 through 1937, when it fell victim to the Civil War (see Figure 15.3). Despite its profile as a frivolous magazine devoted to the promotion of stars, it took a combative stand on several polemical issues; for example, its criticisms of censorship and of the Congreso Hispanoamericano de Cinematografía (Spanish American Film Congress), its defense of Soviet cinema, and its negative views of Hollywood films made in Spanish. This combative stance led it to sack several contributors, such as Gómez Mesa in 1931, while Juan Piqueras was replaced as Paris correspondent by José Luis Salado. From 1935 it was directed by Lope F. Martínez de Ribera. The weekly Cinegramas was launched in Madrid in August 1934, with a large format and copious illustrations, directed by A. Valero de Bernabé. It closed in July 1936 on the outbreak of war. 
During the Civil War, in March 1938 Radio y Cinema: Revista ilustrada de la España Nacional, based in La Coruña in the Nationalist zone, started to publish, moving to Madrid in May 1940, at which point it became a monthly magazine called Radiocinema (though it no longer covered radio). Directed by the Falangist writer Joaquín Romero Marchent, it sought to give political definition to the cinema of the "New Spain," with contributions from Antonio Román, Gómez Mesa, Fernández Cuenca, and José María Salaverría. It continued to publish until July 1963. Its ideological mission was taken up from October 1940 by the influential weekly Primer Plano, the voice of state cinema policy, directed by Manuel Augusto García Viñolas, head of the Departamento Nacional de Cinematografía (National Cinema Department). Its first issue cited Mussolini's notion of the three stages of civilization, characterized by print, photography, and cinema respectively. In March 1941 an editorial by Luigi Chiarini, director of Italy’s Centro Sperimentale di Cinematografía (Experimental Cinema Center), extolled the virtues of the fascist industrial organization of cinema. In the high period of autarky, it was directed by Carlos Fernández Cuenca (from April 1942) and Adriano del Valle (from December 1942 until October 1955). It ceased publication in October 1963.

By contrast, Cámara, founded in Madrid in October 1941 by Tono (Antonio de Lara), took a more reader-friendly and eclectic ideological line, its contributors including Miguel Mihura, Wenceslao Fernández Flórez, Ángel Zúñiga, Alfonso Sánchez, and Enrique Llovet. It ceased publication in 1952. An even more striking contrast was provided by Cine Experimental, directed by the engineer Victoriano López García, founded in Madrid in December 1944. Aimed at an educated elite, it focused on technical and formal questions. Its contributor Carlos Serrano de Osma became managing editor from the fifth issue, taking over as director from the seventh issue until the magazine's demise in 1946. Cine Experimental paved the way for the Instituto de Investigaciones y Experiencias Cinematográficas (Institute for Film Research and Innovation), created in February 1947 within Madrid's Escuela de Ingenieros Industriales (Industrial Engineering School), transformed in 1962 into the Escuela Oficial de Cinematografía (EOC; Official Film School). While filming Abel Sánchez in Barcelona in 1946, Serrano de Osma took further his interests in theoretical inquiry by forming the "Telluric" cinephile group (Los Telúricos) with Pedro Lazaga and the set designer José G. Ubieta.

In July 1953, the film magazine Objetivo was launched in Madrid, taking a dissident line with regard to Francoist cultural politics through its defense of neo-realism. Its editorial board included the communists Bardem, Muñoz Suay, and Ducay as well as the Orteguian philosopher Paulino Garagorri. It supported the May 1955 Salamanca Conversations (see the earlier section on film clubs), to which it devoted its sixth issue, and was closed down by the regime, its last issue appearing in October 1955. Objetivo's contributors included, in addition to the above, Martín Patino, J. F. Aranda, Julio Caro Baroja, Jorge Semprún (under the alias Federico S. Artigas), Manuel Villegas López (returned from exile in Argentina), and the pro-regime García Escudero and Marcelo Arroita-Jáuregui, plus some foreign filmmakers: Cesare Zavattini, Carlo Lizzani, Georges Sadoul, and John Grierson. 


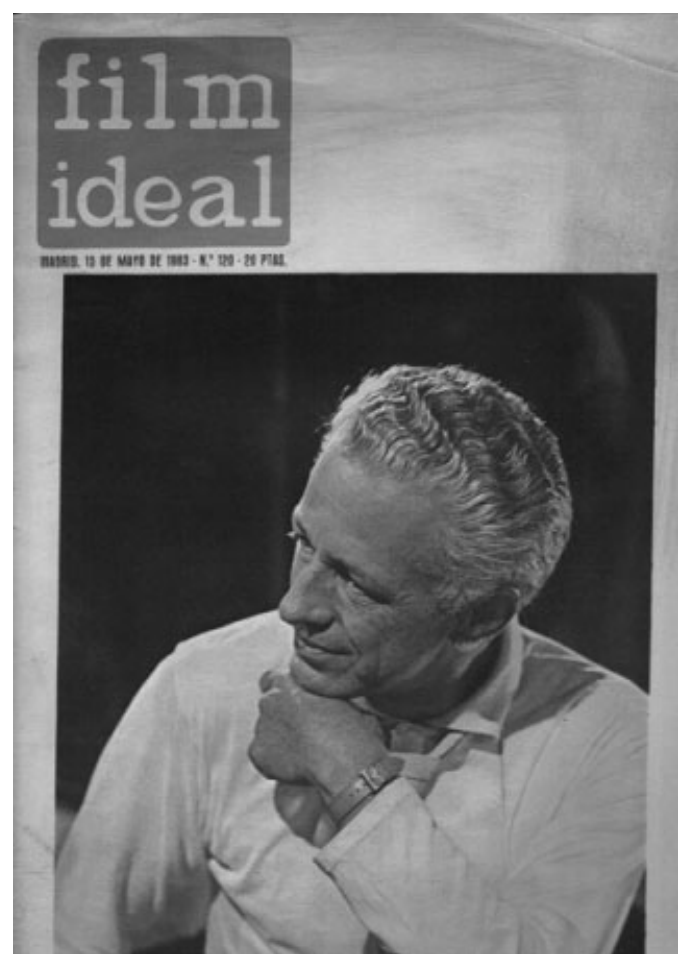

Figure 15.4 Nicholas Ray on the cover of Film Ideal (May 1963). Private collection.

October 1956 saw the launch in Madrid of Film Ideal, published by Publicaciones Populares Católicas (see Figure 15.4). Its founders were José María Pérez Lozano, Juan Cobos, the military officer Félix Martialay, and the Jesuits José A. Sobrino and Félix de Landaburu. A product of the ideological ferment generated by the Salamanca Conversations, in its first period (1956-61) it tenaciously defended cinema as a vehicle for Catholic doctrine and morality. In 1961 it suffered an editorial break-up, with Pérez Lozano leaving to become director of the new magazine Cinestudio (founded in May 1961), which took a more eclectic line. Cobos, Martialay, and Francisco Izquierdo became the new directors of Film Ideal, which now aligned itself with Cahiers du Cinéma's defence of auteurism, emphasis on mise-en-scène, and re-evaluation of Hollywood. Its principal new contributors in the 1960s were José Luis Guarner, Pere (then Pedro) Gimferrer, and Miguel Rubio. In this new phase, a clear political rift developed between Film Ideal and the Madrid monthly Nuestro Cine, which took an orthodox Marxist line. Film Ideal's support for the New Spanish Cinema promoted since 1962 by García Escudero was lukewarm and conflictive. After several more crises and changes of format and frequency, it closed in 1970.

Nuestro Cine had appeared in July 1961 as an offshoot of the theater magazine Primer Acto, both directed by José Monleón (see Figure 15.5). Continuing the line of 


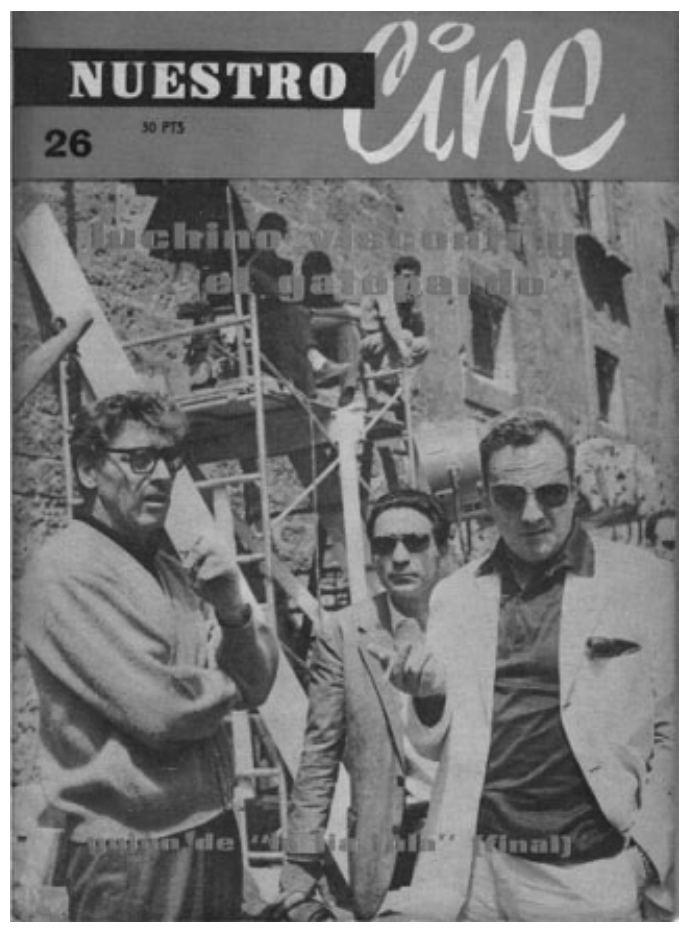

Figure 15.5 Luchino Visconti shooting Il Gatopardo (1963), featured on the cover of Nuestro Cine (January 1964). Private collection.

Objetivo and complementing Cinema Universitario (the magazine of the Salamanca SEU film club, headed by Martín Patino; see the previous section on film clubs), its title paid homage to Piqueras' prewar Nuestro Cinema. Some of its contributors - such as Víctor Erice and Antxon (then Antonio) Eceiza - were products of the Official Film School, and its Marxist ideological line was influenced by the Italian magazine Cinema Nuovo - faithful to the aesthetic theories of the Hungarian Marxist Georg Lukács and the French journal Positif. Its defense of critical realism manifested itself in admiration for Italian cinema (Luchino Visconti, Michelangelo Antonioni, Francesco Rosi, Valerio Zurlini) and its critical attitude to Hollywood, which contrasted with its praise for New American Cinema, British Free Cinema, and French cinéma vérité. It supported García Escudero's appointment as Director General of Film and Theater in July 1962 and the New Spanish Cinema that he promoted. An ideological opponent of Film Ideal, in the latter's period of decline it stole several of its contributors (Vicente Molina Foix, Miguel Marías, Manuel Pérez Estremera), becoming more eclectic as a result. Its last issue appeared in February 1971.

After 1975, film magazines would cease to fulfill the political function that had been so important during the Franco dictatorship (as it had been previously under the Republic), and would increasingly become absorbed into the commercial mainstream. The academic journals that are the exception are discussed in the next section. 


\section{Academic Film Journals since the 1980s (Vicente Sánchez-Biosca)}

In the late 1970s, Spanish film magazines started to divide into those aimed at the general public and academic journals, but with evident overlap. In the former category, Fotogramas (founded in Barcelona in 1946) was in the early 1980s (under the editorship of Elisenda Nadal) offering substantial information about festivals, new releases, and reviews, while Dirigido Por (founded in 1972) followed the French politique des auteurs (see Chapter 5 and Chapter 6), though less so after Enrique Aragonés took over as editor. A new departure has been Cahiers du Cinéma España, created in 2007 under Carlos Heredero's editorship, which has actively championed an auteurist cinema that rarely gets taken up by exhibition circuits.

Academic cinema journals as such are, then, a relatively recent phenomenon in Spain, though they obey the same impulse as in other countries. That is, their appearance is linked to the inclusion of film studies as an academic discipline in Spanish universities, in the field of "comunicación e imagen" (communications and visual media). On the closure in 1976 of the Official Film School, film studies moved into faculties of information science, with Madrid's Universidad Complutense and Barcelona's Universidad Autónoma leading the way. The creation of a university market stimulated new publishing initiatives, such as the book series launched in the 1970s by Fernando Torres in Valencia, and in Barcelona by Gustavo Gili and by Lumen in the communications field. These developments inevitably led to an increase in academic research into cinema. This new space positioned itself at a remove from cinema practitioners on the one hand and from film reviewers and film festivals on the other.

Nonetheless, things are never as simple as they seem and formulas were fairly diversified in the years of the transition to democracy, given that historical and theoretical reflection was at the time tied up with political and social intervention, and given that festivals were (and sometimes still are) arenas that lent themselves to specialization and research. The first journal to attempt to fill the gap left by the disappearance in 1970 of Film Ideal and Nuestro Cine (see the previous section) was La Mirada (1978-9) - a short-lived magazine that only managed four issues but that succeeded in giving voice to a collective need that materialized in a longer-lasting, more substantial publication, Contracampo (see Talens and Zunzunegui 2007). Edited by Francisco Llinàs with the involvement of a group of intellectuals in Madrid, Barcelona, and Valencia, from its first issue of April 1979 Contracampo juggled the roles of critical review, arguing for a politically daring arthouse cinema; of historical journal devoted to the analysis and promotion of film classics at a level that went beyond cinephilia; and of theoretical journal indebted to French structuralism, especially semiotics (Roland Barthes and Julia Kristeva were major reference points) and psychoanalysis (Freud, Lacan, etc.). It is not hard to discern here the traces of publications such as the Cahiers du Cinéma of the late 1960s and 
early 1970s, which, through analysis of the 1920s Russian avant-garde, the French nouveau roman, the May 68 movement and Godard's political militancy, and the New Latin American cinema (among other things), changed the relationship between criticism and politics, engaging in a polemic with Cinéthique, for example. Spanish cinema, film history and theory, and the contemporary scene constituted Contracampo's primary lines of inquiry, set out in its first issue's editorial and maintained until the journal's demise in 1987, after a short period when it published from Valencia. Perhaps symptomatic of this focus was the dossier published in its twentieth volume (March 1981) entitled "El golpe como representación" (The Coup as Representation), in which various contributors analyzed, still close to the events, the random filming by television cameras of Tejero's attempted coup of February 23, 1981.

If Contracampo was characterized by an aesthetic, historical, and (sometimes) political approach, another project, important less for its results than for its focus, was Film-Historia. Created in the early 1990s, around scholars at Barcelona's Universidad Autónoma, it drew on the work of French film historian Marc Ferro in order to analyze cinema's relations with history - a line that its editor José María Caparrós pursued not only through the journal but also through symposia and book publications. Film-Historia's content included less-academic features, such as interviews with directors, and rarely delved into the methodological issues of concern to the French historians that it cited, such as Pierre Sorlin, Michèle Lagny, and, later, J.-P. Bertin-Maghit, Sylvie Lindeperg, Christian Delage, and others.

In the last two decades, the university discipline of film studies has been reconfigured at curricular and research levels, impacting on publications in the field. Cinema is increasingly subsumed in the ambiguous terms "lo audiovisual" (audiovisual media) or "lo comunicativo" (communications), as well as being increasingly included in journals of contemporary history, art, sociology, and even political science. Two Spanish journals stand out as reference points in the systematic study of cinema: Secuencias: Revista de Historia del Cine (Sequences: Journal of Film History) and, especially, Archivos de la Filmoteca (Archives of the Filmoteca). With their well-established publication records, institutional connections, international editorial boards, systems of peer review, and range of disciplinary coverage, both play an important role in the dissemination of state-of-the-art film research.

Secuencias, created in 1994 under the editorship of Alberto Elena, grew out of the Film Program of the Universidad Autónoma de Madrid. Its aim was to give film history the respectability and rigor of other areas of historical inquiry. Although its publication frequency has sometimes been erratic, the journal has maintained and expanded its presence in the market, thanks in part to collaboration with the film publisher Ocho y Medio, again showing the close link between journals and book publication. One of Secuencias' major features is the large amount of space it gives to reviews of books in any of the major academic languages. In 2009 it published the volume El espiritu del caos: Representación y recepción de las imágenes durante el franquismo (The Spirit of Chaos: The Representation and Reception of Images under Francoism), 
edited by Laura Gómez Vaquero and Daniel Sánchez Salas, which brings together a significant number of articles on Spanish cinema published in the journal.

Archivos de la Filmoteca is a special case because of its institutional base, which has guaranteed quality design, abundant illustrations, and an international projection through FIAF (International Federation of Film Archives), not to mention a twenty-year history. Created by Muñoz Suay as part of his founding vision for the Filmoteca de la Generalitat Valenciana (Film Archive of the Valencian Autonomous Government), it first appeared in Spring 1989 and was edited for its first two years by Vicente Ponce. Its line was close to that of Contracampo but with a broader base of collaborators, including the more academic wing of Dirigido Por. In November 1992, Vicente Sánchez-Biosca became editor, with Vicente J. Benet as managing editor, instituting features that at the time were novel: international exchanges, a range of authors writing on a common theme, lack of attention to new releases and film reviews, listings in US databases, and in 2006 the issue of a DVD of the journal's first fifty issues (Archivos de la Filmoteca 2006). The aim of Archivos was not just to turn film studies into a historical field but to embed the journal in the debates taking place in film studies, historical studies, and cultural theory in universities, research centers, and progressive filmotecas with a research agenda. This led to wide collaboration with overseas authors and monographic issues on (for example) the future of narrative at the turn of the millennium (vol. 21), the Middle East (vol. 44), political charisma (vol. 46), the homosexual gaze (vol. 54), Carmen in Hollywood (vol. 51), and documentary (vols. 57-8). The objective is not analysis of the field by a small group of writers but recognition of the fact that the field has been enriched by an infinite range of bibliographic, filmographic, and historical sources that require discussion by the appropriate specialists.

But, if Archivos has contributed to knowledge of cinema as a whole, its main contribution has been its articles on Spanish, and also Latin American, cinema. Encouraging debate between different schools of thought, its studies on Spanish and Latin American cinema have ranged across cultural studies, aesthetic and formal analysis, scholarly historical inquiry, film archaeology as practiced in film archives, auteur theory, and issues of gender and ethnicity, with contributors from many countries. In its nearly sixty-five issues, the journal has been able to offer a range of approaches normally confined to separate book or periodical publications, in keeping with their particular editorial line. The frequent publication of dossiers or monographic issues has favored debate between different views, on occasions including articles on sculpture or stamps when relevant to the iconographic analysis. Among the most innovative volumes are those devoted to television in Spain (vols. 23-4), Latin American mythologies (vol. 31), Brazil between modernism and modernity (vol. 36), the iconography of Franco (vols. 42-3), cinema and the Cuban Revolution (vol. 59), the migration of images of the Spanish Civil War (vols. 60-1), and Guernica (vols. 63-4). The same eclectic approach is illustrated in the 2010 volume in French edited by Benet and Sánchez-Biosca, Visions du 
cinéma espagnol (Visions of Spanish Cinema), containing twelve articles previously published in Archivos.

In summary, Secuencias and Archivos de la Filmoteca stand on a par with international research-oriented publications such as Screen, which has played a central role in British film studies through its openness to theoretical innovation, while their breadth of focus, methodology, and subject matter differentiate them from the specialization of, for example, the Italian Griffithiana (linked to the Giornate del Cinema Muto (Silent Cinema Festival) and limited to cinema's first three decades), the French 1895, and the English-language Film History (which focuses on historical issues). The synergy between all of these magazines is shown by the fact that they share many contributors.

\section{References}

Alberich, F. (1993) Carne de fieras. Madrid: Filmoteca Española.

Alberich, F. (1997) Raza: Cine y propaganda en la inmediata posguerra. Archivos de la Filmoteca 27 (October): 50-61.

Archivos de la Filmoteca (2006) Interactive DVD containing vols. 1-50 of the journal (1989-2005). Valencia: Institut Valencià de Cinematografia (IVAC).

Benet, V. and Sánchez-Biosca, V. (2010) Visions du cinéma espagnol. Paris: L’Harmattan.

Del Amo, A. with Ibáñez Ferradas, M. L. (1996) Catálogo general del cine de la Guerra Civil. Madrid: Cátedra / Filmoteca Española.

Gómez Vaquero, L. and Sánchez Salas, D. (2009) El espiritu del caos: Representación y recepción de las imágenes durante el franquismo. Madrid: Ocho y Medio.

Gorostiza, J. (1997) Directores artísticos del cine español. Madrid: Cátedra / Filmoteca Española.

Gubern, R. (1999) Proyector de luna: La Generación del 27 y el cine. Barcelona: Anagrama.

Llinás, F. (1989) Directores de fotografía del cine español. Madrid: Filmoteca Española.

Peirats, J. (1935) Lo que podría ser un cine social. Barcelona: La Revista Blanca.

Pérez Merinero, C. and Pérez Merinero D. (1975) Del cinema como arma de clase: Antología de "Nuestro Cinema" 1932-35. Valencia: Fernando Torres Editor.

Riambau, E. (2008) Productores en el cine español. Madrid: Cátedra / Filmoteca Española.

Riambau, E. and Torreiro, C. (1998) Guionistas en el cine español. Madrid: Cátedra / Filmoteca Española.

Talens, J. and Zunzunegui, S. (2007) Contracampo: Ensayos sobre teoría e historia del cine. Madrid: Cátedra.

\section{Further Reading}

Caparrós Lera, J. M. (2000) Cine y vanguardismo: "Documentos Cinematográficos" y "Cine-Club Monterols" (1955-1966). Barcelona: Flor del Viento. 
Hernández Marcos, J. L. and Butrón, E. (1978) Historia de los cineclubs en España. Madrid: Ministerio de Cultura.

Nieto Ferrández, J. (2009) Cine en papel: Cultura y crítica cinematográfica en España (19391962). Valencia: Filmoteca Generalitat Valenciana.

Tubau, I. (1983) Crítica cinematográfica española. Bazin contra Aristarco: La gran controversia de los años 60. Barcelona: Universitat de Barcelona.

Tuñón, J. (2009) Relaciones de celuloide: El Primer Certamen Cinematográfico Hispanoamericano. Madrid, 1948. In: Lida, C. E. (ed.) México y España en el primer franquismo, 1939-1950: Rupturas oficiales, relaciones oficiosas. Mexico City: El Colegio de México, pp. 121-61. 


\section{Contents}

Acknowledgments viii

List of Figures $\quad$ ix

List of Contributors xviii

1 Introduction 1

Jo Labanyi and Tatjana Pavlović

$\begin{array}{lll}\text { Part I Reframing the National } & 13\end{array}$

2 Transnational Frameworks $\quad 15$

Gerard Dapena, Marvin D'Lugo, and Alberto Elena

Brad Epps

4 Negotiating the Local and the Global: Andalusia,

the Basque Country, and Galicia

José Colmeiro and Joseba Gabilondo

Part II The Construction of the Auteur

5 Auteurism and the Construction of the Canon 113 Marvin D'Lugo and Paul Julian Smith

6 Strategic Auteurism Antonio Lázaro-Reboll, Steven Marsh, Susan Martin-Márquez, and Santos Zunzunegui 
Part III Genre

7 Comedy and Musicals

Steven Marsh, Chris Perriam, Eva Woods Peiró, and Santos Zunzunegui

8 Melodrama and Historical Film

Jo Labanyi, Annabel Martín, and Vicente Rodríguez Ortega

Jo Labanyi, Antonio Lazaro-Reboll, and Vicente Rodriguez Ortega

\section{Part IV Stars as Cultural Icons}

10 The Construction of the Star System

Kathleen M. Vernon and Eva Woods Peiró

11 Stars, Modernity, and Celebrity Culture

Tatjana Pavlovic, Chris Perriam, and Nuria Triana Toribio

\section{Part V Image and Sound}

12 Photography, Production Design, and Editing

Vicente Sánchez-Biosca

13 Soundtrack

Romain Gubern and Kathleen M. Vernon

Part VI The Film Apparatus: Production, Infrastructure, and Audiences

14 Censorship, Film Studios, and Production Companies Josetxo Cerdán, Román Gubern, Jo Labanyi, Steven Marsh, Tatjana Pavlovic, and Nuria Triana Toribio

15 Film Clubs, Festivals, Archives, and Magazines Ferran Alberich, Román Gubern, and Vicente Sánchez-Biosca

16 Audiences Manuel Palacio and Kathleen M. Vernon

Part VII Relations with Other Media

17 Cinema, Popular Entertainment, Literature, and Television 
Part VIII Beyond the Fiction Film

18 Newsreels, Documentary, Experimental Film, Shorts, and Animation

Josetxo Cerdan and Vicente Sánchez-Biosca

\section{Part IX Reading Films through Theory}

19 Isabel Coixet's Engagement with Feminist Film Theory:

From $\mathrm{G}$ (the Gaze) to $\mathrm{H}$ (the Haptic)

Susan Martin-Márquez

20 Becoming a Queer (M)Other in/and/through Film:

Transsexuality, Trans-subjectivity, and Maternal

Relationality in Almodóvar's Todo sobre mi madre

Julian Daniel Gutiérrez-Albilla

21 The Space of the Vampire: Materiality and Disappearance in the Films of Iván Zulueta

Brad Epps

Index 